\title{
Importance of submarine groundwater discharge (SGWD) and seawater cycling to material flux across sediment/water interfaces in marine environments
}

\author{
George M. Simmons, Jr \\ Department of Biology, Virginia Polytechnic Institute and State University, Blacksburg, Virginia 24061, USA
}

\begin{abstract}
The movement of water across sediment/water interfaces is very important to the ecology of aquatic habitats. Submarine groundwater discharge (SGWD) occurs primarily by advective flow and may be due to a variety of factors. In nearshore marine environments, the major factor is probably groundwater flow from upland regions. In oceanic environments, SGWD is probably influenced more by tides and surge action. SGWD, therefore, represents various mixtures of fresh groundwater and seawater This paper summarizes the first regional study of SGWD and its attendant solutes in shallow estuarine, continental shelf and coral reef habitats, and calls attention to the magnitude of water volumes which appear to be circulating through marine sediments. Data on SGWD from sites in the Florida Keys and on the southeastern continental shelf of the U.S. indicate that water movement across sediment/water interfaces is a common occurrence at least to water depths of 30 to $35 \mathrm{~m}$. Discharge values from the Florida Keys were $8.91 \mathrm{~m}^{-2} \mathrm{~d}^{-1}(\mathrm{~N}=344)$ for depths $<27 \mathrm{~m}$ and $5.4 \mathrm{l} \mathrm{m}^{-2} \mathrm{~d}^{-1}(\mathrm{~N}=261)$ for depths of ca 27 to $39 \mathrm{~m}$. On the southeastern continental shelf, discharge ranged between ca 6 and $20 \mathrm{l} \mathrm{m}^{-2} \mathrm{~d}^{-1}$ One site was found in $20 \mathrm{~m}$ depth where there was a persistent negative hydraulic head and a mean influx of seawater to the sediments $\left(\mathrm{ca} 10.8 \mathrm{l} \mathrm{m}^{-2} \mathrm{~d}^{-1}\right)$. Even though geohydrological models would predict coupling of SGWD with landbased hydraulic heads, definitive lower salinity SGWD could not be detected. The driving force seems to be subtidal pumping and much of the discharge measured was probably recycled seawater. This research also demonstrated that SGWD serves to move dissolved solutes into the water column, and could be an important link in benthic-pelagic coupling in continental shelf ecosystcms.
\end{abstract}

\section{INTRODUCTION}

This paper reports the first comprehensive bulk flow measurements of submarine groundwater discharge and seawater cycling through marine sediments, and suggests the importance of these processes to material flux across sediment/water interfaces in marine environments (Fig. 1). Material flux across sediment/ water interfaces in marine environments is extremely important to biological productivity and may be important to geological mineralization processes. Historically, material flux has been measured by 2 methods: in situ and diffusion gradient methods (Zeitzschel 1979). Here, movement of water and dissolved material across sediment/water interfaces were measured by a third method, that of bulk flow, using seepage meters and mini-piezometers as described by Lee $(1977,1980)$, and Lee \& Cherry (1978).

Submarine groundwater discharge and seawater cycling

Initial interest in seawater cycling focused on the relationship between fresh, groundwater inflow to the sea and seawater intrusion into fresh, groundwater supplies (Reilly \& Goodman 1985). Over a period of several decades numerous mathematical equations and models have been derived for interactions between these 2 systems and their interface properties. Glover (1959), building on the research of earlier workers, developed a mathematical expression to describe 


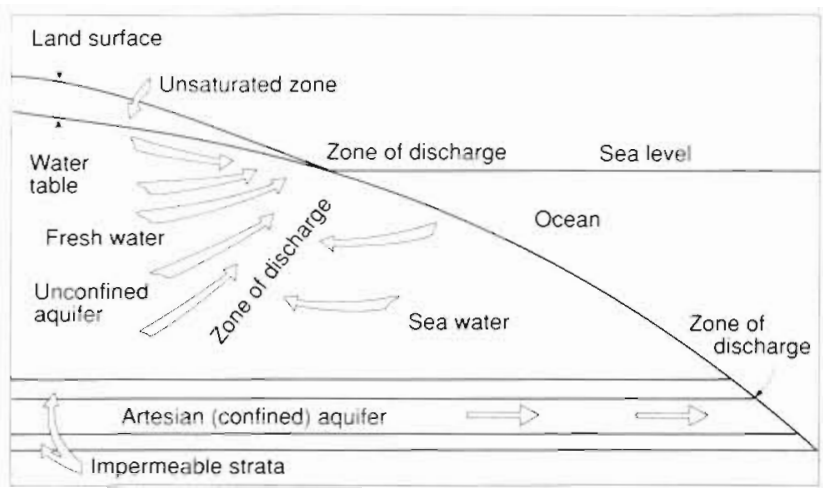

Fig. 1. Schematic diagram showing the relationship between fresh and salt groundwater reservoirs and the advective flow that results between them (modified from Johannes 1980)

the interface between fresh and salt groundwater in a coastal aquifer that accounted for the movement and discharge of freshwater. Cooper (1959) developed a hypothesis to explain the mixing zone, or zone of dispersion, and the continuous circulation of seawater observed in various field studies, and attempted to quantify the amount of mixing due to tidiai fiuctuations. Henry $(1959,1964)$ advanced the concepts further by quantitatively corroborating Cooper's hypothesis and used an advection-diffusion equation to account for hydrodynamic dispersion. Kohout $(1960,1964)$ was one of the first investigators during this period to suggest and quantify the continuous cycling of seawater as a result of hydrodynamic dispersion. Since the early 60's, numerous mathematical models have been developed to satisfy given constraints of geological formations in coastal regions, and the history of these quantitative developments has been described by Reilly \& Goodman. (1985) in excellent detail. The important conclusion from an ecological perspective was that seawater can and does cycle in an advective way through sediments due to a fresh groundwater hydraulic head.

Other mechanisms also have been suggested which contribute to seawater movement through marine sediments. Kohout $(1965,1967)$ and Kohout et al. (1977) postulated thermal convection as a possible mechanism for seawater circulation in the Floridean plateau. Riedl (1971) and Riedl \& Machan (1972) demonstrated the significance of surf action on the movement of seawater through marine sediments in the intertidal and subtidal zone of sandy beaches. Riedl et al. (1972) also developed a mathematical equation to explain seawater circulation through marine sediments by means of subtidal pumping. Reflux, defined as a type of saline fluid convection (Simms 1984), has also been proposed as a mechanism of seawater cycling (Newell et al. 1953, Adams \& Rhodes 1960, Simms 1984). Details of Kohout Convection, reflux, and cycling along coastal mixing zones have been discussed in greater detail by Simms (1984).

\section{Material flux}

Another scientific development occurring parallel to the geological studies of seawater cycling, but seemingly isolated from them, was a series of studies dealing with material flux, particularly nutrients, across the sediment/ water interface in marine environments. Historically, such measurements have been made by means of in situ or diffusion calculation measurements (Zeitzschel 1979). Such studies have been conducted by Rowe et al. (1975), Rowe \& Smith (1977), Krom \& Berner (1980), Phoel et al. (1981), Callender \& Hammond (1982), Duursma \& Smies (1982) and others. This research indicates that a considerable amount of material is available in the sediment to move across the sediment/ water interface into the ocean and, using the above methods, this movement has been demonstrated. These methods, however, rely on passive or diffusion movements, and have not considered bulk flow, or seawater cycling, as a vehicle for material flux.

The movement of water across sediment/water interfaces is important biologically because it sets the microclimdic conditions for micro-and macrofauna inhabiting sediment (Riedl et al. 1972). Without a seawater cycling process, sediments would become reduced and inhabitable only by anaerobic or microaerophilic organisms. The fact that the sediments are oxidized indicates that circulation is occurring (Riedl et al. 1972). Seawater cycling also is extremely important from the standpoint of nutrient enrichment. The concept of benthic-pelagic coupling is a relatively new concept in marine ecology (Nixon et al. 1984), and it has been demonstrated that in large oceanic systems, such as continental shelf areas, regeneration of nutrients from benthic environments may be sufficient to sustain pelagic primary productivity (Rowe et al. 1975, Rowe \& Smith 1977). Cahoon (1987) has found evidence to suggest the importance of such coupling in Onslow Bay, North Carolina (USA). Seawater cycling is also important geologically because of the mineralization. that occurs at sediment/water interfaces and may be important in explaining processes of dolomitization (Simms 1984) and possibly phosphate deposits.

The existence of localized submarine groundwater discharge along the southeastern Atlantic coast has been known for some time (Manheim 1967). The data reported by Manheim (1967) contained salinity measurements as the only evidence of freshwater presence, but no information regarding chemical compounds, which would be important to benthic ecologists. Kohout (1964) and Kohout \& Kolipinski (1967) appear to have been the first investigators to study the importance of freshwater seepage into marine ecosystems in shallow environments. Their studies, conducted along the shore of Biscayne Bay, Florida (USA), showed a 
definite relationship between biological zonation and groundwater discharge into the bay.

Johannes (1980) also presented significant information on the ecological significance of submarine groundwater discharge. While acknowledging the fact that groundwater discharge to the sea is widespread, '... overlooking the fact could lead to serious misinterpretation of ecological data in studies of coastal pollution, of benthic zonation and productivity, and of the flux of dissolved substances between bottom sediments and overlying water.'

D'Elia et al. (1981) reported the influence of groundwater-derived nitrate discharge as a nitrogen source to the waters of Discovery Bay, Jamaica, and speculated on the importance of such discharges to reef growth in general. Marsh (1977) also found that groundwater seepage had a major influence on nutrient levels on a Guam fringing reef flat. More recently, Lewis (1987) reported the importance of groundwater seepage to nutrient loading onto coral reefs at Barbados, West Indies. Koch et al. (1969) noted that green sea turtles Chelonia mydas may use groundwater seepage as a marker for location and recognition of island breeding grounds. Harden Jones (1980) suggested that plaice Pleuronectes platessa may also use groundwater seepage as a landmark for identifying spawning grounds.

Benthic biological communities can also influence material flux across sediment/water interfaces (Calender \& Hammond 1982). Bioturbation by benthic macrofauna alters sediment structure by producing a relatively homogeneous surficial sediment profile, whereas burrow formation alters sediment geometry and increased sediment porosity (Aller 1978, 1980, 1982, McCaffrey et al. 1980). Diaz \& Schaffner (1990) provided an excellent review relating abundance and production of benthic organisms to chemical diagenesis and nutrient flux across the sediment/water interface. The relative importance of benthic faunal activity and SGWD has not been compared.

Bulk flow measurements with seepage meters and mini-piezometers

Seepage meters and mini-piezometers have been used to study groundwater influx in lakes and streams (Lee 1977, 1989, Lee \& Cherry 1978, Lee \& Hynes 1978, Lock \& John 1978, Erickson 1981); in an icecovered Antarctic lake (Wharton et al. 1989); in nearshore estuarine environments (Bokuniewicz 1980, Bokuniewicz \& Zeithin 1980, Zimmerman et al. 1985, Simmons 1988, 1989, Maclntyre et al. 1989, Reay \& Gallagher 1990, Simmons et al. 1990); and in marine habitats (Lewis 1987, Simmons \& Love 1987, Simmons \& Netherton 1987)

\section{STUDY LOCATIONS}

Over several years, a number study sites were used to measure submarine groundwater discharge (SGWD) and seawater cycling in 2 locations along the southeastern coast of the U.S. (Fig. 2). The Key Largo National

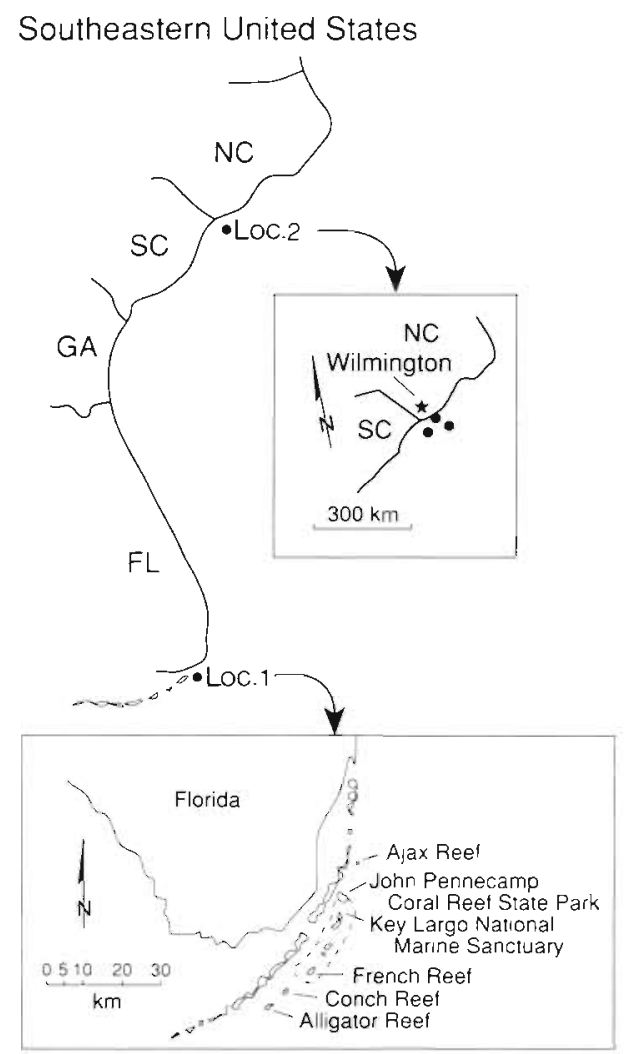

Fig. 2. Geographic study locations along the southeastern coast of the United States

Marine Sanctuary was the first location used in the study because the original measurements made in SGWD occurred off French Reef in the Sanctuary (Simmons \& Love 1987) in conjunction with studies on stromatolite analogs (Simmons et al. 1985). An area north of the Sanctuary off Ajax Reef in Biscayne National Park also was studied, as well as an area south of the Sanctuary off Conch Reef. In all 3 areas, depth ranges extended between ca $10 \mathrm{~m}$ and $35 \mathrm{~m}$. The second location was off Wilmington, North Carolina, in Onslow and Long Bays (Fig. 2). This study location was on the continental shelf and depth ranged between ca 10 and $33 \mathrm{~m}$.

\section{METHODS}

Collections of SGWD for quantitative water quality analyses and for measuring bulk seepage flux cross the ocean bottom were accomplished by using seepage 
meters as described by Simmons \& Netherton (1987) and submarine mini-piezometers as described by Lee \& Cherry (1978). Piezometers were established by driving a galvanized pipe, set on a nylon point, into the sediment with sledge hammers to a depth of $1 \mathrm{~m}$. Plastic tubes (i.e. the piezometer), with perforations wrapped in nylon mesh at one end, were placed inside the pipe, and the pipe was withdrawn. Sediment was then packed very tightly around the tube before use. Sites were selected at random at a given depth and discharge was measured as frequently as time permitted. In some cases, collection could be made at 3 to $4 \mathrm{~h}$ sampling intervals. In other cases, collections could only be made on a 12 to $24 \mathrm{~h}$ basis. The availability of divers, depth considerations, repetitive dive schedules, and weather determined sampling frequency.

During the Key Largo study, an underwater manometer was developed to measure hydraulic heads in seepage meters and piezometers (Simmons \& Netherton 1987) (Fig. 3). This device consisted of an inverted U-shaped Tygon tube filled with air and water and mounted to a meter stick. One side was open to the sea at the working depth, and the other side was attached to either a seepage meter or a mini-piezometer. This device was used to measure hydraulic head differences

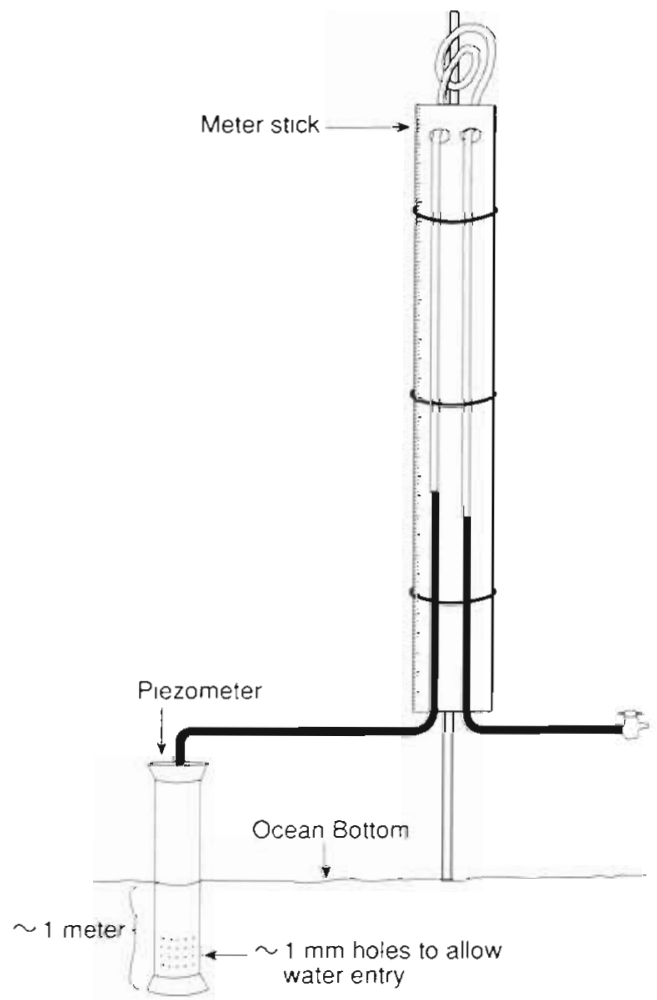

Fig. 3. Diagram of a manometer connected to a piezometer Both piezometers and seepage meters could be attached to a bag for collecting water or to a manometer for measuring hydraulic head. Fluid in the tubes is seawater and hydraulic head could be read directly. The piezometer was set ca $1 \mathrm{~m}$ into the sediments between the open water at the sediment/water interface, and some depth (usually $1 \mathrm{~m}$ ) in the sediments.

In order to compare water influx with discharge (efflux), 2 seepage meters were constructed from large metal drums and a collection bag was mounted inside each drum as well as on the outside. When deploying the seepage meters in the conventional manner, collection bags were always attached to the outside of the seepage meter. These seepage meters were deployed on a sandy bottom, free of any apparent burrowing organisms, in ca $10 \mathrm{~m}$ off French Reef.

Samples for water quality analyses were collected in acid-washed Nalgene bags that were rinsed 3 times in deionized/distilled water. Samples for nutrient analyses were preserved with sulfuric acid while samples for metal analyses were preserved with nitric acid. Analyses in both cases followed methods of the Environmental Protection Agency (1983). Cation concentrations were measured on a Perkin-Elmer Model 4000 or 5000 atomic absorption spectrophotometer. Standards for $\mathrm{Ca}, \mathrm{Mg}, \mathrm{Mn}, \mathrm{K}$, and $\mathrm{Na}$ were made up in deionized water and measured by flow injection analyses. Standards tor $\mathrm{Cd}, \mathrm{Cu}, \mathrm{Pb}, \mathrm{N}_{1}$, and $\mathrm{Zn}$ were made up in substitute ocean water and likewise analyzed by flow injection. Chelation with ammonium pyrrolidine dithiocarbamate and extraction with MIBK was used to measure the concentration of $\mathrm{Cd}, \mathrm{Cu}, \mathrm{Pb}$, and $\mathrm{Ni}$.

Standards for nutrient analyses were made in substitute ocean water. Nitrate analyses generally followed E.P.A. Method 353.2 using cadmium reduction, or concentrations were measured with a Dionex ion chromatograph (Model No. System 14). Ammonia determinations were made using the Phenate Method (E.P.A. Method 353.3) and Total and Dissolved Phosphate were analyzed by the Ascorbic Acid Method (E.P.A. Method 365.2).

The salinity of seawater and water from the seepage meters and mini-piezometers was measured with a hydrometer read to the fourth decimal place. Corresponding density/salinity tables were used to convert hydrometer measurements to salinity values (American Public Health Ass. et al. 1976). Temperature measurements were made with calibrated long stem thermometers. Oxygen measurements were made using a micro-Winkler technique and titration with $0.0025 \mathrm{~N}$ sodium thiosulfate. The technique for micro-Winkler analyses involved reducing reagent volumes and titrant normality in relationship to the volume sampled (Welch 1948)

Non-parametric statistical analyses were used to test significant differences between samples in various studies. In general, either the Wilcoxon Rank Sum Test or the Kruskal-Wallis $H$-test were used for these purposes (Dixon \& Massey 1969). Analyses were performed with the PC statistical package Number Cruncher (Hintze 1987). 


\section{RESULTS}

\section{Location 1}

During the period October 1984 to July 1986, several hundred measurements of SCiWD were made at this location. The mean discharge rate for all measurements in 27 to $39 \mathrm{~m}$ depth was $225.0 \mathrm{~mL} \mathrm{~m}^{-2} \mathrm{~h}^{-1}\left[5.4 \mathrm{I} \mathrm{m}^{-2} \mathrm{~d}^{-1}\right]$ $(\mathrm{N} \simeq 261)$, while the mean of all values above this depth range was $372.0 \mathrm{ml} \mathrm{m}^{-2} \mathrm{~h}^{-1}\left[8.9 \mathrm{l} \mathrm{m}^{-2} \mathrm{~d}^{-1}\right](\mathrm{N}=$ 344).

During summer 1986, a sufficient number of divers was assembled to conduct 2 diel studies off French Reef. The results are presented in Figs. 4 \& 5. Fig. 4 shows congruent discharge patterns of periodicity in the Back Reef, Reef Crest, and Fore Reef sites, and highest discharge rates were between the slack periods

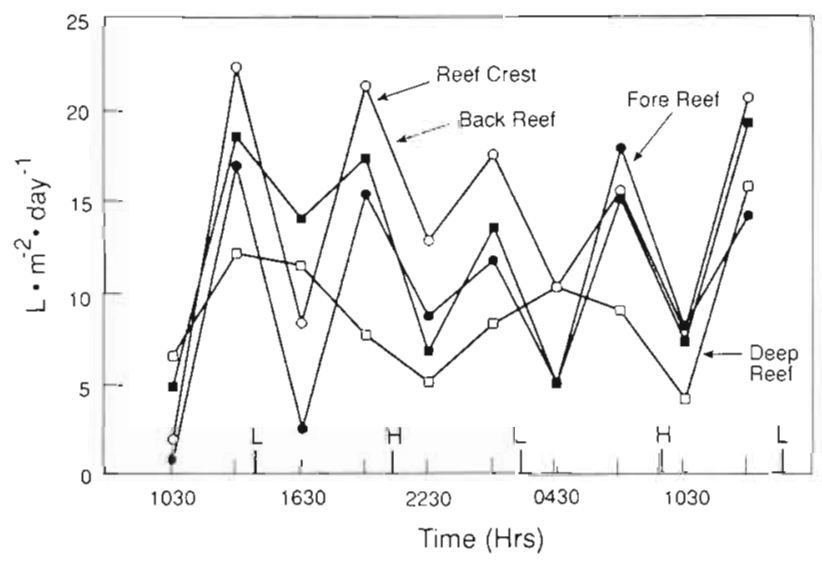

Fig. 4. SGWD off Key Largo, Florida, on July 20 to 21, 1986, with respect to tides over a $24 \mathrm{~h}$ period. $\mathrm{H}$ and $\mathrm{L}$ : slack periods at high and low tides, respectively. Each data point is the mean of 3 replicates

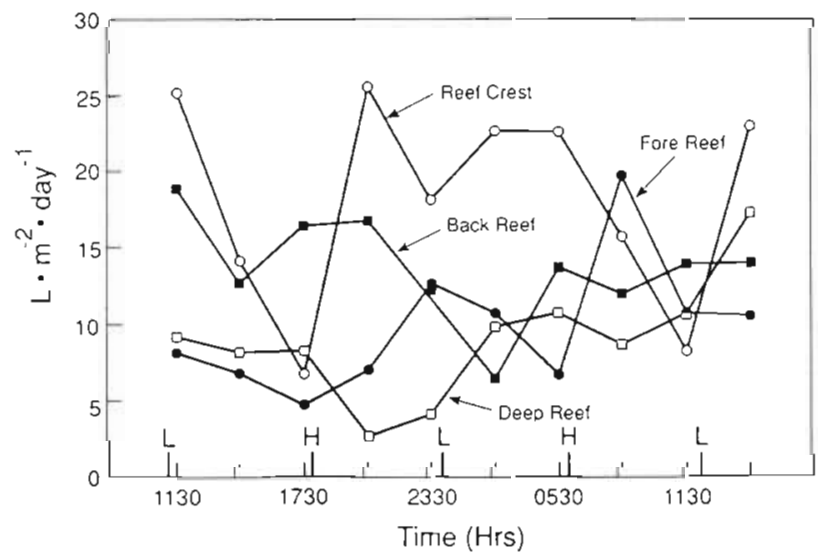

Fig. 5. SGWD off Key Largo, Florida, on July 31 to August 1 , 1986, with respect to tides over a 24 h period. H and L: slack periods at high and low tides, respectively. Each data point is the mean of 3 replicates of high and low tides. At the Deep Reef Site, the periodicity was different and there was an inverse relationship between discharge rate and tidal height. On July 31 and August 1, 1986, this exercise was repeated (Fig. 5). In contrast to the first study, there was very little correlation between the shallow stations across the reef. However, the Deep Reef Site continued to show a weak inverse correlation with tidal height.

In order to test the question of influx versus efflux, a total of 24 measurements were made using the 2 seepage meters in the Forereef site (ca $10 \mathrm{~m}$ ) during a $24 \mathrm{~h}$ study. The results showed a very significant difference between the 2 directions ( $p=0.01$ ) with the greater volume of water moving from the sediments $(\vec{x}=279.8$ \pm 196.2 vs $55.6 \pm 38.6 \mathrm{ml} \mathrm{d}^{-1}$ ).

Hydraulic head measurements with manometers were important in this study. The hydraulic head measurements from the Key Largo Site were made only at the research site off French Reef in the Key Largo National Marine Sanctuary. In most cases, readings were 2 to $3 \mathrm{~mm}$ positive (indicating outflow from the sediment), with occasional readings of 6 to $8 \mathrm{~mm}$. Neutral and negative heads were also measured and in some cases a given seepage meter or piezometer would change sign after a few hours. The significance of the negative readings was not appreciated until the 1987 summer research in Onslow Bay at Location 2.

Of particular interest is a set of hydraulic head measurements made of French Reef in $30.5 \mathrm{~m}$ in conjunction with the diel study of July 31 to August 1, 1986 (Table 1). In this exercise, 3 piezometers, placed $1.0 \mathrm{~m}$

Table 1. Hydraulic head measurements (mm) from piezometers set $1.0 \mathrm{~m}$ below ocean bottom in $30.3 \mathrm{~m}$ depth

\begin{tabular}{|cccc|}
\hline Time (h) & Piez. No. 1 & Piez. No. 2 & Piez. No. 3 \\
\hline $07: 40$ & -7 & +3 & +1 \\
$10: 45$ & -4 & +3 & +1 \\
$13: 42$ & -6 & +2 & +1 \\
$16: 42$ & -8 & +2 & +1 \\
$19: 41$ & -8 & +2 & +1 \\
$22: 44$ & -6 & +1 & 0 \\
$01: 40$ & -8 & +3 & +1 \\
$04: 44$ & -8 & +1 & 0 \\
$07: 40$ & -6 & +4 & +1 \\
$10: 33$ & -7 & +4 & +1 \\
$14: 05$ & -6 & +4 & +2 \\
\hline
\end{tabular}

into the sediment, were set up in a line across the bottom perpendicular to the reef, ca $10 \mathrm{~m}$ apart. Piezometer \#1 consistently read negative, ca -6 to -8 $\mathrm{mm}$; 2 read positive, ca +2 to $+4 \mathrm{~mm}$; and \#3, closest to the reef face, read positive, but only ca $+1 \mathrm{~mm}$. These readings suggested that water was entering the sediment at the \#1 piezometer, and discharging 
primarily at the \#2 piezometer. The data show there were definitely hydraulic head differences across the sediment/water interface over small spatial distances.

The original discovery of submarine groundwater discharge off Key Largo was made in 1983 while conducting studies on stromatolite analogs characteristic of the sea (Simmons et al. 1985). These water samples were of low salinity and contained a high metal and nutrient content (Simmons \& Love 1987). Unfortunately, this exact discharge point was never re-located, and subsequent salinity measurements of submarine groundwater discharge samples did not indicate direct evidence of a fresh groundwater presence even though there was considerable variation around mean values (Simmons 1986).

Table 2 summarizes selected cation concentrations in SGWD from seepage meters and piezometers. Unfortunately, the variability in measurement masks possible differences of $\mathrm{Ca}, \mathrm{Na}, \mathrm{K}$, and $\mathrm{Mg}$, but there were differences in the concentrations of $\mathrm{Mn}, \mathrm{Fe}, \mathrm{Cu}, \mathrm{Zn}, \mathrm{Cd}$. $\mathrm{Pb}$, and $\mathrm{Ni}$ between SGWD and ambient seawater. These differences were even greater in the piezometer samples (Table 3), and comparison of the piezometer samples with the samples from the seepage meters suggests that some of the cations were deposited at or near the sediment/water interface. These data also were corroborated by a more exhaustive study of metal and pesticide contamination in coral reef sediments by Skinner \& Jaap (1986).

Table 4 shows the effect of SGWD on the nutrient composition of the water in comparison to ambient seawater. As with the salinity data, some of the samples showed nitrate and total phosphate concentrations above ambient seawater, other samples were at or below seawater levels. However, the data do demonstrate the potential for positive nutrient flux into pelagic waters as a result of SGWD. The higher nitrate levels may be explained by the potential for nitrogen fixation in the sediments as measured by Simmons et al. (1987) beneath benthic algal mats in the study area.

The quantity of ion flux as a result of SGWD at Location 1 was compared to the ion concentration in several major southeastern rivers at their fall lines (Table 5). The study area off Key Largo was adjusted to

Table 2. Summary of cation composition of SGWD from seepage meters from several locations and depths (6.1 to $36.5 \mathrm{~m}$ ) at Location 1

\begin{tabular}{|c|c|c|c|c|c|c|c|c|c|c|c|}
\hline & $\mathrm{Ca}$ & $\begin{array}{l}\mathrm{Na} \\
\text { (mg }\end{array}$ & $\begin{array}{c}\mathrm{K} \\
\left.1^{-1}\right)\end{array}$ & $\mathrm{Mg}$ & $\mathrm{Mn}$ & $\mathrm{Fe}$ & $\mathrm{Cu}$ & $\begin{array}{c}\mathrm{Zn} \\
\left(\mu \mathrm{g} \mathrm{l}^{-1}\right)\end{array}$ & $\mathrm{Cd}$ & $\mathrm{Pb}$ & $\mathrm{Ni}$ \\
\hline \multicolumn{12}{|c|}{ March 14-27, 1985} \\
\hline \multicolumn{12}{|c|}{ Ambient (seawater) } \\
\hline Mean & 432 & 11800 & 404 & 1354 & 14 & 20 & $<1$ & -16 & $<0.4$ & $<1$ & $<1$ \\
\hline $\begin{array}{l}\mathrm{SD} \\
\mathrm{N}=5\end{array}$ & 13.0 & 1303.8 & 20.7 & 20.7 & 5.5 & 0.0 & 0.0 & 10.8 & 0.42 & 0.0 & 0.0 \\
\hline \multicolumn{12}{|c|}{ Seepage meters } \\
\hline Mean & 414 & 11143 & 409 & 1273 & 10 & 16 & $\sim 1.9$ & 37 & 1.7 & 14.5 & 2.9 \\
\hline $\mathrm{SD}$ & 77.2 & 1463.9 & 19.5 & 237.6 & 3.8 & 9.3 & 2.7 & 39 & 0.5 & 1.7 .3 & 3.4 \\
\hline \multicolumn{12}{|c|}{ July $2-4,1985$} \\
\hline \multicolumn{12}{|c|}{ Ambient (seawater) } \\
\hline Mean & 351 & 11627 & 300 & 1294 & 28 & 111 & 3 & 12.5 & $<1$ & 2.8 & 1.1 \\
\hline $\begin{array}{l}\mathrm{SD} \\
\mathrm{N}=4\end{array}$ & 25 & 529 & 33 & 66 & 6 & 25 & 3 & 8.9 & 0 & 1.6 & 0.8 \\
\hline \multicolumn{12}{|c|}{ Seepage meters } \\
\hline Mean & 365 & 11554 & 328 & 1252 & 36 & 145 & 3 & 26.1 & $<1$ & 3.5 & 2.3 \\
\hline $\begin{array}{l}\mathrm{SD} \\
\mathrm{N}=14\end{array}$ & 22 & 711 & 30 & 72 & 7 & 34 & 1.4 & 15.0 & 0 & 3.8 & 1.8 \\
\hline
\end{tabular}

Table 3. Concentrations of cations in water from piezometers at $30.5 \mathrm{~m}$ off French Reef, September 1-2. 1985

\begin{tabular}{|c|c|c|c|c|c|c|c|c|c|c|c|}
\hline & $\mathrm{Ca}$ & $\begin{array}{l}\mathrm{Na} \\
\operatorname{lmg}\end{array}$ & $k$ & $\mathrm{Mg}$ & $\mathrm{Mn}$ & $\mathrm{Fe}$ & $\mathrm{Cu}$ & $\begin{array}{c}\mathrm{Zn} \\
\left(\mathrm{ug} \mathrm{l}^{-4}\right)\end{array}$ & $\mathrm{Cd}$ & $\mathrm{Pb}$ & $\mathrm{Ni}$ \\
\hline & $\begin{array}{l}320 \\
380\end{array}$ & $\begin{array}{l}12000 \\
12000\end{array}$ & $\begin{array}{l}344 \\
329\end{array}$ & $\begin{array}{l}1430 \\
1280\end{array}$ & $\begin{array}{l}50 \\
40\end{array}$ & $\begin{array}{l}255 \\
210\end{array}$ & $\begin{array}{l}9 \\
2\end{array}$ & $\begin{array}{l}210 \\
320\end{array}$ & $\begin{array}{l}<1 \\
<1\end{array}$ & $\begin{array}{l}1 \\
1\end{array}$ & $\begin{array}{l}2 \\
1\end{array}$ \\
\hline Mean & 350 & 12000 & 337 & 1355 & 45 & 233 & 6 & 265 & $<1$ & 1 & 2 \\
\hline
\end{tabular}


Table 4. Nutrient concentrations ( $\mathrm{mg} \mathrm{l}^{-1}$ ) in seepage meters from various sites and depths at Location 1

\begin{tabular}{|c|c|c|}
\hline & Nitrate-N & Total phosphate-P \\
\hline \multicolumn{3}{|c|}{ Ambient (seawater) } \\
\hline Mean & 0.03 & 0.02 \\
\hline $\mathrm{SD}$ & 0.03 & 0.03 \\
\hline$N$ & 7 & 7 \\
\hline \multicolumn{3}{|c|}{ Seepage meters } \\
\hline Mean & 0.10 & 0.06 \\
\hline $\mathrm{SD}$ & 0.05 & 0.06 \\
\hline$N$ & 15 & 14 \\
\hline
\end{tabular}

approximate the drainage basins of the respective rivers above the fall line, and to account for hard coral bottom through which little water circulation would be expected. Only those cations are presented that showed a significant difference between concentrations in seepage meter discharge and ambient seawater. As Table 5 shows, the amount of material that can be re-introduced to pelagic environments by SGWD can be quite significant when compared to quantities of similar ions brought in by major rivers, although what is measured as SGWD may be mostly recycled seawater.

During the research off French Reef, the idea was considered that seepage flux might be driven by elevated temperatures in the sediments in comparison to ambient seawater. To test this idea, a long stem thermometer was placed in a shallow well that was established ca $1.0 \mathrm{~m}$ beneath the ocean floor in ca $33 \mathrm{~m}$ water depth. A similar thermometer was added to a seepage meter for comparative purposes. Mean ambient seawater temperature during the experiment at $33 \mathrm{~m}$ was $27.9^{\circ} \mathrm{C}( \pm 0.6, \mathrm{~N}=23)$; mean well temperature was $27.5^{\circ} \mathrm{C}( \pm 0.5, \mathrm{~N}=23)$; and, the mean temperature from the test seepage meter was $27.8^{\circ} \mathrm{C}$ $( \pm 0.4, N=9$ ). In a few cases the seawater temperature was equal to, but in no case lower than, the temperature in the seepage meter or the sediments.

During the early phases of the study in 1983-84 off
Key Largo, researchers working at depths of ca 30 to $35 \mathrm{~m}$ noted the abundance of pencil-sized holes ringed by sediment cones. These small holes were originally thought to be associated with SGWD because no burrowing animals could be found in the tubes beneath the holes. Four separate studies were conducted during 1984 and 1985 to compare SGWD between sandy areas with no holes and sandy areas that had ca 50 to 75 holes/seepage meter The results showed $60.7 \pm 54.2 \mathrm{ml} \mathrm{m}^{-2} \mathrm{~h}^{-1}(\mathrm{~N}=54)$ from areas with no holes versus $69.8 \pm 68.1 \mathrm{ml} \mathrm{m}^{-2} \mathrm{~h}^{-1}(\mathrm{~N}=51)$ from areas with holes. Further collection efforts indicated the holes were burrows made by a thalassinidean shrimp, Axiorygma nethertoni (Kensley \& Simmons 1988). If burrowing organisms did indeed make a difference to SGWD rate, the difference was not apparent with this species which was very abundant in the deeper study areas ( $>30 \mathrm{~m}$ ).

\section{Location 2}

Experiments were conducted at Location 2 during the summers of 1987 and 1988. Shallow stations were established in ca 10,15 , and $20 \mathrm{~m}$. In contrast to all the other studies, SGWD was never obtained at the station in $20 \mathrm{~m}$, and the hydraulic head was consistently negative $(-1.4 \mathrm{~cm})$ during the $5 \mathrm{~d}$ the site was worked. After having the seepage meter bags empty several times before flux could be measured, enough seawater was finally added so that on the last day, 3 replicates indicated a mean flux of ca $450 \mathrm{ml} \mathrm{m}^{-2} \mathrm{~h}^{-1}\left(10.8 \mathrm{~lm}^{-2} \mathrm{~d}^{-1}\right)$ was entering the sediments at this site.

At the $15 \mathrm{~m}$ site, discharge rates were initially very low Hydraulic head measurements at this site were at first negative, then zero, then finally shifted to positive values by the end of the study period. When hydraulic head measurements became positive, SGWD was collected in the seepage meters.

Discharge at the $10 \mathrm{~m}$ site was always high. Hydraulic heads could not be measured at this site because of the water's murkiness, and because heavy

Table 5. Ion discharge concentrations $\left(\mathrm{mg} \mathrm{s}^{-1}\right)$ from selected rivers and adjusted comparative discharge concentrations from seepage meters (recalculated from Simmons \& Netherton 1987)

\begin{tabular}{|lccccccccc}
\hline $\begin{array}{l}\text { River/ } \\
\text { seepage meter }\end{array}$ & Mn & Fe & Cu & Zn & Cd & Pb & Ni & Nitrates & $\begin{array}{c}\text { Total } \\
\text { phosphorus }\end{array}$ \\
\hline James River & $1.4 \times 10^{3}$ & $2.4 \times 10^{4}$ & 11 & 987 & 11 & 664 & 11 & $4.7 \times 10^{4}$ & $2.9 \times 10^{4}$ \\
Seepage meter & $5.0 \times 10^{4}$ & $1.7 \times 10^{5}$ & $5.5 \times 10^{3}$ & $6.7 \times 10^{4}$ & $2.8 \times 10^{3}$ & $1.9 \times 10^{4}$ & $5.5 \times 10^{3}$ & $8.2 \times 10^{4}$ & $4.7 \times 10^{4}$ \\
Savannah River & $4.0 \times 10^{3}$ & $4.9 \times 10^{4}$ & 515 & $4.3 \times 10^{3}$ & 17 & $3.8 \times 10^{3}$ & - & $10.6 \times 10^{4}$ & $2.8 \times 10^{4}$ \\
Seepage meter & $7.2 \times 10^{4}$ & $2.5 \times 10^{5}$ & $8.1 \times 10^{3}$ & $9.9 \times 10^{4}$ & $4.1 \times 10^{3}$ & $2.8 \times 10^{4}$ & $8.1 \times 10^{3}$ & $12.1 \times 10^{4}$ & $6.9 \times 10^{4}$ \\
Altamaha River & $1.6 \times 10^{4}$ & $1.4 \times 10^{5}$ & $1.2 \times 10^{3}$ & $3.9 \times 10^{3}$ & 20 & $3.5 \times 10^{3}$ & - & $11.4 \times 10^{4}$ & $3.3 \times 10^{4}$ \\
Seepage meter & $1.0 \times 10^{5}$ & $3.5 \times 10^{5}$ & $1.4 \times 10^{5}$ & $1.5 \times 10^{4}$ & $5.7 \times 10^{3}$ & $3.9 \times 10^{4}$ & $1.5 \times 10^{4}$ & $17.0 \times 10^{4}$ & $9.7 \times 10^{4}$ \\
\hline
\end{tabular}


surge tore out the station during the middle of the exercise and the manometer was lost. No nutrient data was available from this site becauase (1) seawater was added to the bags as at the 15 and $20 \mathrm{~m}$ sites to estimate seawater influx to the sediment, and (2) the shallow station had to be replaced near the end of the experiment.

Another research site included in this study was located on the southeastern continental shelf in Long Bay ca $32 \mathrm{~km}$ offshore and in depths between ca 30.5 and $31.5 \mathrm{~m}$. This area showed positive discharge rates (ca $5.0 \mathrm{l} \mathrm{m}^{-2} \mathrm{~d}^{-1}$ ) and salinities that fluctuated around that of seawater. Because the seepage meters did not have time to flush sufficiently, nutrient analyses were performed only on water collected from piezometers that had flushed several times their volume. No ammonia was detected either in seawater or SGWD samples from the piezometers. No soluble reactive phosphate was detected in seawater samples, but a mean of $0.84 \mathrm{mg} \mathrm{l}^{-1}$ was measured in the piezometers. Mean total phosphate in piezometer samples was 0.97 $\mathrm{mg} \mathrm{l}^{-1}$. Of particular interest was the concentration of dissolved oxygen. Measurements trom the piezometers showed a mean of $2.5 \mathrm{mg} \mathrm{l}^{-1}$, while ambient seawater at those depths had a mean of $6.7 \mathrm{mg} \mathrm{l}^{-1}$. The data suggest that phosphate was being carried across the sediment/water interface in slightly oxygenated water.

The last experiment at this location was conducted ca $37 \mathrm{~km}$ offshore in an area known locally as 23 Mile Rock. This area is part of a ledge system located along the southeastern continental shelf off the Carolina coasts. Fig. 6 shows the results for discharge rates with respect to tides. The data suggest SGWD was independent of tides and the highest discharge measured was ca $20.0 \mathrm{l} \mathrm{m}^{-2} \mathrm{~d}^{-1}$ The importance of the measurements is that if discharge decreased with distance from shore,

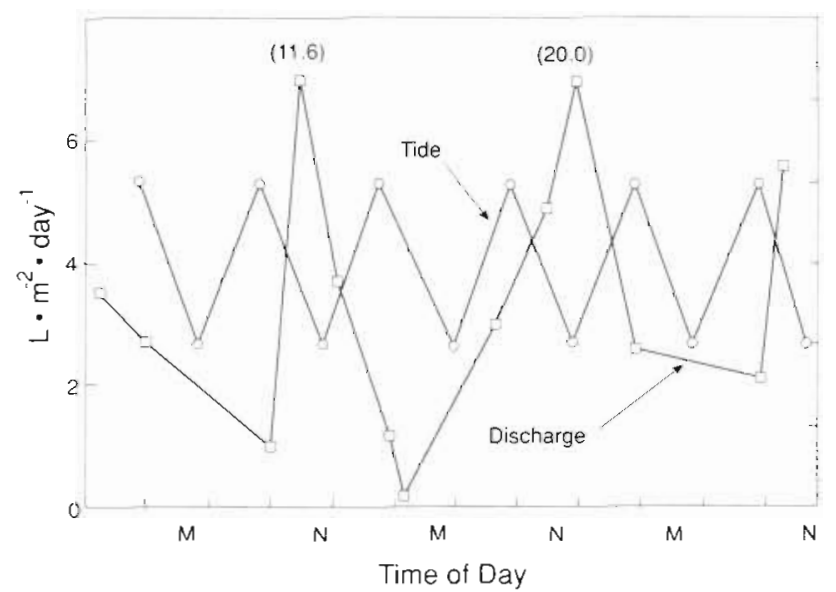

Fig. 6. SGWD at 23 Mile Rock off the North Carolina coast on June 12 to 15,1987 , in relation to tides. $M$ and $V$ : times of midnight and noon, respectively. Each data point is the mean of 3 repilictes very little discharge should have occurred at this site. The discharge $37 \mathrm{~km}$ offshore in $33 \mathrm{~m}$, however, was greater than the mean discharge (ca $6.31 \mathrm{~m}^{-2} \mathrm{~d}^{-1}$ ) measured in $10 \mathrm{~m}$ and only $500 \mathrm{~m}$ offshore.

\section{DISCUSSION}

The data presented here suggest that SGWD may be a very important ecological process in coastal marine environments at least to a depth of $33 \mathrm{~m}$ on the southeastern continental shelf. The SGWD was driven by a positive hydraulic head, salinity was variable, and evidence of material flux with SGWD was measured.

One of the basic questions deals with the factors that cause a positive hydraulic head and drive the system. The most obvious of these is the land-based fresh, groundwater system. This source is most obvious in shallow, nearshore environments (freshwater or marine) (Simmons et al. 1990). An investigator can usually verify the presence of upland groundwater by measuring changes in salinity or conductivity at the sediment/water interface. Farther offshore, the reiationship to the land-based groundwater system becomes more confusing because of inadequate knowledge about regional flow patterns and subsurface geology. Moreover, even if freshwater was driving the system, its integrity would be lost across the distances it must travel through mixing with subsurface saline waters. For example, Riggs \& Manheim presented data (unpubl.) which showed water of lower salinity beneath continental shelf sediments off North Carolina (Fig. 7). Our collections were not made at any of their specific sites, and we did not detect water of decreased salinity in our seepage meters or piezometers. Whether the presence of the freshwater was masked by mixing with

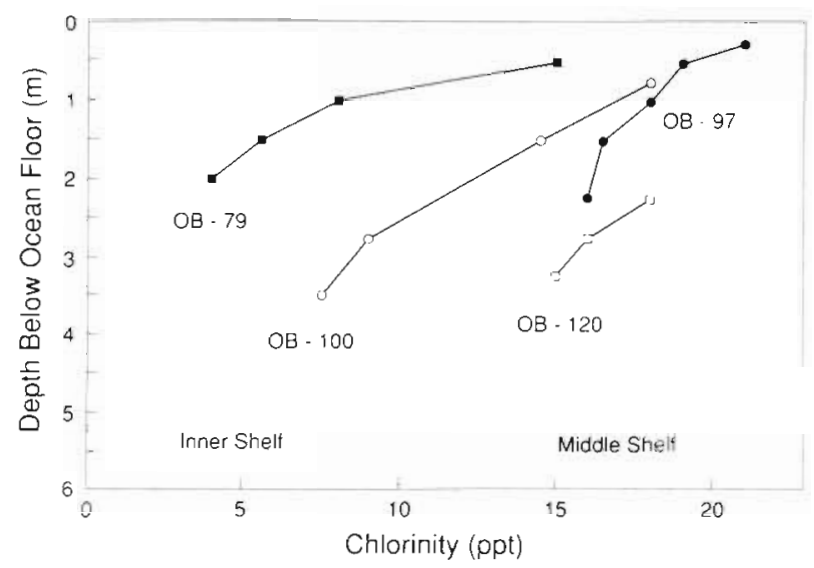

Fig. 7 Changes in chlorinity with sediment core depth from continental shelf cores off North Carolina. Data kindly provided by Dr Stan Riggs, Geology Department, East Carolina University, Greenville, NC 
seawater or our stations simply missed the low salinity water which they detected remains to be determined.

Some very indirect evidence of the effect of landbased groundwater levels on SGWD is presented in Table 6 using data from the Key Largo study site. Before April 1985, south Florida (Everglades and

Table 6. Rainfall and discharge summary for south Flonda $1985-86$

\begin{tabular}{|lcccc|}
\hline Time & $\begin{array}{c}\text { Rainfall } \\
(\mathrm{cm})\end{array}$ & $\begin{array}{c}\text { Discharge } \\
\left(1 \mathrm{~m}^{-2} \mathrm{~d}^{-1}\right)\end{array}$ & $\begin{array}{c}\text { Depth } \\
(\mathrm{m})\end{array}$ & $\mathrm{N}$ \\
\hline < April 1985 & -6 to -33 & 0.7 & $<30.5$ & 231 \\
& & 2.1 & $\sim 30.5$ & 180 \\
June 1986 & +2 to +9 & 11.6 & $<30.5$ & 255 \\
& & 9.6 & $\sim 30.5$ & 150 \\
\hline
\end{tabular}

Southwest Coast, and Lower East Coast regions) had -15 to $-33 \mathrm{~cm}$ below normal rainfall for that period of the year and mean discharge rates were $0.71 \mathrm{~m}^{-2} \mathrm{~d}^{-1}$ from depths above $30.5 \mathrm{~m}$. Mean discharge rates for depths $>30.5 \mathrm{~m}$ were $2.1 \mathrm{l} \mathrm{m}^{-2} \mathrm{~d}^{-1}$. During late 1985 and early 1986, south Florida received an above average amount of rainfall and by June 1986 the region was 2 to $9 \mathrm{~cm}$ above normal for the year (NOAA 1984, 1985 , 1986). The corresponding discharge rates were 11.61 $\mathrm{m}^{-2} \mathrm{~d}^{-1}$ for depths $<30.5 \mathrm{~m}$ and $9.61 \mathrm{~m}^{-2} \mathrm{~d}^{-1}$ for depths $>30.5 \mathrm{~m}$. Whether such differences in precipitation are directly connected to SGWD at depth and distance offshore remains to be investigated

Simms (1984) summarized 2 ideas that also could contribute to SGWD in deeper marine environments. These ideas dealt with reflux and thermal convection. It is possible that in tropical coral reef environments, water of higher salinity would exist in lagoon areas due to evaporation and contribute to a discharge off a reef face in deeper water because of the greater density. This may indeed contribute to some of the measurements presented here. Robblee et al. (1989) reported elevated salinities in Florida Bay adjacent to the research sites off Key Largo. In most cases, evaporation exceeded runoff and hypersaline $(>35 \%$ ) conditions prevailed throughout much of the Bay. Salinity values as high as $52 \%$ were recorded.

The idea of thermal convection, as suggested by Kohout (1967), may have some merit, but the significance of such convection cells will require further investigation. At least our temperature measurements ca $1 \mathrm{~m}$ below the sediment/water interface indicated that elevated sediment temperatures would not be a reasonable mechanism for the positive hydraulic heads and SGWD.

Riedl et al. (1972) presented one of the more logical explanations offered to date which may explain most of the SGWD that we have measured in offshore, deep environments. Based upon their study, they presented evidence to indicate that surge pumping is a major force that circulates seawater through sediments in continental shelf ecosystems (Fig. 8). The magnitude of this cycling process is enormous. For example, they calculated that the subtidal pump filters ca $95.7 \mathrm{~km}^{3}$ $\mathrm{yr}^{-1}$ through continental shelf margins world-wide. This means that a volume equal to all oceans would filter through continental margin sediments in $\mathrm{Ca}$ 14000 yr. While this time period is very short, geologically speaking, it is only one quarter the time required to exchange the ocean's volume through evaporation, precipitation, and drainage back through river systems. In order to move such volumes of water through continental shelf margins, the yearly percolation across a unit shelf area is more than 5 times greater than precipitaton on land. At these exchange rates, a volume of water equal to the neritic water over the southeastern continental shelf would be completely filtered through continental margin sediments within 5 to $10 \mathrm{mo}$, depending upon sea state.

Riedl et al. (1972) also presented a model to predict seawater cycling through the sediments in relation to 'sea state' (Table 7). Based on their model, they concluded net flux would be zero, i.e. there would be as much water entering as leaving the sediments. However, as Table 7 and other data presented in this paper show, there appears to be a net flux of SGWD out of the sediments and our measurements in offshore, deep marine environments are 3 to 10 times greater than predicted by the model under a given sea state. On one occasion in Onslow Bay (Site 2, $20 \mathrm{~m}$ ), a negative hydraulic head and influx was measured for 5 continuous days. Measurements such as these suggest more complicated relationships than hydraulic heads driven by land-based freshwater systems and/or subtidal pumping. If the hypothesis proposed by Riedl et al. (1972) and the data collected thus far withstand the scrutiny of

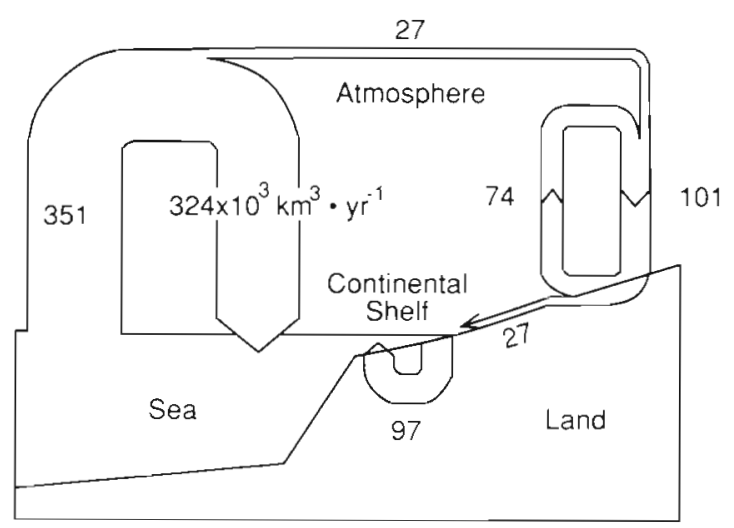

Fig. 8. Schematic diagram of the relationship of water circulation through continental shelf sediments to global water exchange (modified from Riedl et al. 1972) 
Table 7. Calculated seepage velocity $\left(\mathrm{nm} \mathrm{s}^{-1}\right)$ as a function of wave period and depth (Riedl \& Machan 1972), and values measured during this study

\begin{tabular}{|c|c|c|c|c|}
\hline $\begin{array}{l}\text { Wave period } \\
\text { (s) }\end{array}$ & $10 \mathrm{~m}$ & \multicolumn{2}{|c|}{$20 \mathrm{~m}$} & $30 \mathrm{~m}$ \\
\hline$<6$ & 27 & \multicolumn{2}{|c|}{6} & 1.2 \\
\hline $6-7$ & 52 & \multicolumn{2}{|c|}{25} & 9 \\
\hline $8-9$ & 70 & \multicolumn{2}{|c|}{37} & 20 \\
\hline $10-11$ & 70 & \multicolumn{2}{|c|}{40} & 27 \\
\hline $12-13$ & 70 & \multicolumn{2}{|c|}{40} & 27 \\
\hline$>13$ & 65 & \multicolumn{2}{|c|}{40} & 27 \\
\hline \multicolumn{5}{|c|}{ Values measured in 1988 (wave period $<6$ s): } \\
\hline & $10 \mathrm{~m}$ & $15 \mathrm{~m}$ & $20 \mathrm{~m}$ & $30 \mathrm{~m}$ \\
\hline Mean & 160 & 200 & 80 & 120 \\
\hline Range & $16-440$ & $12-560$ & $12-240$ & $12-560$ \\
\hline
\end{tabular}

further scientific investigation, the significance of SGWD and/or seawater cycling on marine ecosystems could be very significant.

Acknowledgements. This project was supported by the National Oceanic and Atmospheric Administration (NOAA), National Undersea Research Center at the University of North Carolina in Wilmington, NC, during the years 1982 to 1987 with numerous ship cruises and much logistic support; the Sanctuary Programs Division of NOAA fOrder No. NA84AAA03722); a sabbatical funded by the United States Geological Survey, Water Resources Division, Reston, Virginia and Atlanta, Georgia; and, the Department of Biology, Virginia Polytechnic Institute and State University, Blacksburg, Virginia. Permits to work in Key Largo National Marine Sanctuary and Key Biscayne National Park were kindly provided, respectively, by Dr Nancy Foster of NOAA's Sanctuary Programs Division, and Dr Stephen Cofer-Shabica, Key Biscayne National Park. The author wishes to express his appreciation to all those individuals who specifically assisted with this project, especially the deep diving efforts, in particular, those of John Netherton, Linton Leary, Guy Snyder, Nathan Simmons, and Dr Ken Elliott. Dr Steven Vogel, Zoology Department, Duke University, Durham, NC, kindly introduced me to the papers by Riedl. The author also appreciates the support of Dr Stan Riggs, Geology Department, East Carolina University, Greenville, NC, in providing information about salinity in sediment cores from the continental shelf off North Carolina.

\section{LITERATURE CITED}

Adams, J. E., Rhodes, M. L. (1960). Dolomitization by seepage refluxion. Bull. Am. Ass. Petrol. Geol. 44: 1912-1920

Aller, R. C. (1978). The effects of animal-sediment interactions in geochemical processes near the sediment-water interface. In: Wiley, M. L. (ed.) Estuarine interactions Academic Press, New York, p. 157-172

Aller, R. C. (1980). Quantifying solute distributions in the bioturbated zone of marine sediments by defining an aver- age microenvironment. Geochim. cosmochim. Acta 44 $1955-1965$

Aller, R. C. (1982). The effects of macrobenthos on chemical properties of marine sediments and overlying water In: McCall, P. L., Tevesz, M. J. S. (eds.) Animal-sediment relations. Plenum Press, New York, p. 53-102

American Public Health Association, American Water Works Association, Water Pollution Control Federaton (1976). Standard methods for the examination of water and wastewater, 14th edn. American Public Health Association, Washington, D.C.

Bokuniewicz, H. (1980). Groundwater seepage into Great South Bay, New York. Estuar. coast. mar. Sci. 10: 437-444

Bokuniewicz, H., Zeithin, M. (1980). Characteristics of the groundwater seepage into Great South Bay. Marine Science Research Center, S.U.N.Y Stony Brook, Spec. Rpt. 35

Cahoon, L. (1987). The role of sediment-water column interactions in the continental shelf ecosystem. In: Mitchell, C. T. (ed.) Proc. Amer. Assoc. Underwater Sci., 947 Newhall St. Costa Mesa, CA 92627, p. 171-180

Callender, E., Hammond. D. E. (1982). Nutrient exchange across the sediment-water interface in the Potomac River estuary. Estuar. coast. Shelf Sci. 15: 395-413

Cooper, H. H. (1959). A hypothesis concerning the dynamic balance of freshwater and saltwater in a coastal aquifer. J. geophys. Res. 64: 461-467

D'Elia, C. F., Webb, K. L., Porter, J. W. (1981). Nitrate-rich groundwater inputs to Discovery Bay, Jamaica: a significant source of $\mathrm{N}$ to local reefs? Bull. mar. Sci. 31: 903-910

Diaz, R. J., Schaffner, L. C. (1990). The functional role of estuarine benthos. In: Haire, M., Krome, E. C. (eds.) Perspectives on the Chesapeake Bay, 1990: Advances in Estuarine Sciences. Chesapeake Research Consortium, Gloucester Point, VA. CBP/TRS41/90, p. 25-56

Dixon, W. J. Massey, Jr, F. J. (1969). Introduction to statistical analysis, 3rd edn. McGraw-Hill, New York

Duursma, E. K., Smies, M. (1982). Sediments and transfer at and in the bottom intertacial layer. In: Kullenberg, G. (ed.) Pollutant transfer and transport in the sea, chap. 3. CRC Press, Inc., Boca Raton, p. 101-139

Environmental Protection Agency (1983). Methods for chemical analysis of water and wastes. EPA-600/4-79-020

Erickson, D. R. (1981). A study of littoral groundwater seepage at Williams Lake, Minnesota using seepage meters and wells. M.S. thesis, The University of Minnesota, Minneapolis

Glover, R. E. (1959). The pattern of freshwater flow in a coastal aquifer J. geophys. Res. 64 : 457-459

Harden Jones, F. R. (1980). The migration of plaice (Pleuronectes platessa) in relation to the environment. In: Bardach, J. E., Magnuson, J. J., May, R. C., Reinhart, J. M. (eds.) Fish behavior and its use in the capture and cultures of fishes. ICLARM Conf. Proceed. 5. International Center for Living Aquatıc Resources Management, Manila, Philippines, p. 383-399

Henry, H. R. (1959). Salt intrusion into fresh-water aquifers. J. geophys. Res. 64: 1911-1919

Henry, H. R. (1964). Elfects of dispersion on salt encroachment in coastal aquifers. In: Cooper, H. H. et al. (eds.) Sea water in coastal aquifers. U.S. Geol. Surv., Water-Supply Pap. $1613-$ C. p. $70-84$

Hintze, J. (1987). Number Cruncher Statıstıcal System. Pubi. by Dr J. L. Hintze, Kaysville, UT

Johannes, R. E. (1980). The ecological significance of the submarine discharge of ground water Mar. Ecol. Prog. Ser 3: 365-373 
Kensley, B., Simmons, G. M., Jr (1988). Axiorygma nethertoni, a new genus and species of Thalassinidean shrimp from Florida (Decapoda: Axiidae). J. Crust. Biol. 8: 657-667

Koch, A. L., Carr, A., Ehrenfeld, D. W. (1969). The problem of open-sea navigation: the migration of the green turtle to Ascension Island. J. theor Biol. 22: 163-179

Kohout, F. A. (1960). Cyclic flow of salt water in the Biscayne Aquifer of southeastern Florida. J. geophys. Res. 65: $2132-2141$

Kohout, F A. (1964). The flow of fresh water and salt water in the Biscayne Bay Aquiter of the Miami area, Florida. Seawater in coastal aquifers. U.S. Geol. Surv., Water Supply Pap. 1616-C: 12-32

Kohout, F. A. (1965). A hypothesis concerning cyclic flow of salt water related to geothermal heating in the Floridian Aquifer Trans. N.Y. Acad. Sci. Ser 2 28: 249-271

Kohout, F. A. (1967). Groundwater-flow and the geothermal regime of the Floridian Plateau. Trans. Gulf Coast Ass. Geol. Soc. 17. 339-354

Kohout, F. A., Kolipinski, M. C. (1967). Biological zonation related to groundwater discharge along the shore of Biscayne Bay, Miami, Florida. In: Lauff, G. H. (ed.) Estuaries. Conf. on Estuaries, Jekyll Island, GA. Publ. No. 83, Am. Assoc. Adv. Sci., Washington, D.C., p. 488-499

Kohout, F. A., Henry, H. R., Banks, J. E. (1977). Hydrology related to geothermal conditions of the Floridian Plateau. In: Smith, D. L., Griffin, G. M. (eds.) The geothermal nature of the Floridian Plateau. Spec. Publ. No. 21, Florida Bureau of Geology, Tallahassee, p. 1-41

Krom, M. D., Berner, R. A. (1980). The diffusion coefficients of sulfate, amonium, and phosphate ions in anoxic marine sediments. Limnol. Oceanogr 25: 327-337

Lee, D. R. (1977). A device for measuring seepage flux in lakes and estuaries. Limnol. Oceanogr. 22: 140-147

Lee, D. R. (1980). Groundwater-solute influx. Limnol. Oceanogr 25: 183-186

Lee, D. R., Cherry, J. A. (1978). A field exercise on groundwater flow using seepage meters and mini-piezometers. J. Geol. Educ. 27: 6-10

Lee, D. R., Hynes, H. B. N. (1978). Identification of groundwater discharge zones in a reach of Hillman Creek in Southern Ontario. Poll. Res. Can. 13: 121-133

Lewis, J. B. (1987). Measurements of groundwater seepage flux onto a coral reef: spatial and temporal variations. Limnol. Oceanogr. 32: 1165-1169

Lock, M. A., John, P. J. (1978). The measurement of groundwater discharge into a lake by a direct method. Int. Rev. ges. Hydrobiol. 63: 271-275

MacIntyre, W. G., Johnson, G. H., Reay, W G., Simmons, Jr, G. M. (1989). Groundwater non-point sources of nutrients to the southern Chesapeake Bay. In. Proc. Groundwater Issues and Solutions in the Potomac River Basin/ Chesapeake Bay Region. Co-sponsored by the Assoc of Ground Water Scientists, et al., George Washington University, Washington, D.C., p. 83-104

Manheim, F. T. (1967). Evidence for submarine discharge of water on the Atlantic continental slope of the southern United States, and suggestions for further search. Trans. N.Y Acad. Sci. Ser. II. 28: 839-853

Marsh, J. A., Jr (1977). Terrestrial inputs of nitrogen and phosphates on fringing reefs on Guam. Proc. Third Int. Coral Reef Symp., Univ. of Miami, p. 331-336

McCaffrey, R. J., Myers, A. C., Davey, E., Morrison, G., Bender, M., Luedtke, N., Cullen, P., Froelich, P., Klinkhammer, G. (1980). The relation between pore water chemistry and benthic fluxes of nutrients and manganese in Narragansett Bay, Rhode Island. Limnol. Oceanogr 25: 31-44
Newell, N. D., Rigby, J. K., Fischer, A G., Whiteman, A. J. Hilcox, J. E., Bradley, J. S. (1953). The Permian reef complex of the Guadalupe Mountains region, Texas and New Mexico. W H. Freeman Co., Salt Lake (ity

Nixon, S. W., Kelley, J. R., Furmas, B. N., Oviatt, C. A., Hale, S.S. (1979). Phosphorus regeneration and the metabolism of coastal marine botton communities. In: Tenore, K. R. Coull, B. C. (eds.) Marine benthic dynamics. Univ of South Carolina Press, Columbia, p. 219-242

Nixon, S. W., Pilson, M. E. Q., Oviatt, C. A., Donaghay, P., Sullivan, B., Seitzinger, S., Rudnick, D., Frithsen, J. (1984) Eutrophication of a coastal marine ecosystem - an experimental study using the MERL Microcosms. In: Fasham, M. J R. (ed.) Flows of energy and materials in marine ecosystems: theory and practice. Plenum Press, New York, p. 135-195

NOAA (National Oceanic and Atmospheric Administration) (1984, 1985, 1986). Climatological data for south Florida NOAA Natl. Climatic Data Center, Asheville, NC, Vols. 88 89,90

Phoel, W. C., Webb, K. C., DElia, C. F. (1981). Inorganic nitrogen regeneration and total oxygen consumption by the sediments at the mouth of the York River, Virginia. In: Neilson, B. J., Cronin, L. E. (eds.) Estuaries and nutrients. Humana Press, Clifton, p. 607-618

Reay, W., Gallagher, D. (1990). Advective transport of interstitial solutes in near-shore estuarine environments. In: Mihursky, J. A., Chaney, A. (eds.) New perspectives in the Chesapeake system. Proceedings of the Chesapeake Bay Research Conference, Dec. 4-9, 1990, Baltimore, MD. CRC Publ. 137. Chesapeake Research Consortium, Solomons, MD, p. 651-662

Reilly, T. E., Goodman, A. S. (1985). Quantitative analysis of saltwater-freshwater relationships in groundwater systems - a historical perspective. J. Hydrol. 80: 125-160

Riedl, R. (1971). How much seawater passes through sandy beaches? Int. Revue ges. Hydrobiol. 56: 923-946

Riedl, R., Machan, R. (1972). Hydrodynamic patterns in lotic intertidal sands and their bioclimatological implications. Mar Biol. 13: 179-209

Riedl, R., Huang, N., Machan, R. (1972). The subtidal pump: a mechanism of interstitial water exchange by wave action. Mar. Biol. 13: 210-221

Robblee, M. B., Tilmant, J. T., Emerson, J. (1989). Quantitative observations on salinity. Bull. mar. Sci. 44:523

Rowe, G. T., Clifford, C. H., Smith, K. L. (1975). Benthic nutrient regeneration and its coupling to primary productivity in coastal waters. Nature, Lond. 255: 215-217

Rowe, G. T., Smith, K. L., Jr (1977). Benthic-pelagic coupling in the mid-Atlantic bight. In: Coull, B. C. (ed.) Ecology of marine benthos. Univ. of South Carolina Press, Columbia, p. 55-66

Simmons, G. M., Jr (1986). Groundwater discharge quality in a deep coral reef habitat. NOAA Technical Rept. Ser., Off. Ocean and Coastal Resource Mgt., Sanctuary Programs Div., Final Report

Simmons, G. M., Jr (1988). The importance of submarine groundwater discharge to nutrient flux in coastal marine environments. In: Lynch, M. P., Krome, E. C. (eds.) Proc. Understanding the Estuary: Adv. Chesapeake Bay Research. CRC Publ. No. 29, CBP/TRS 24/88. Chesapeake Research Consortium, Solomons, MD, p. 225-269

Simmons, G. M., Ir (1989). The Chesapeake Bay's hidden tributary: submarine groundwater discharge. In: Proc Groundwater Issues and Solutions in the Potomac River Basin/Chesapeake Bay Region. Co-Sponsored by the Assoc. of Ground Water Scientists and Engineers, et al., George Washington University, Washington, D.C. p. 9-30 
Simmons, G. M., Jr, Hall, G. B., Mikell, A. T., Love, F. G. (1985). A comparison of biogeological properties of a deepwater marine stromatolite analog with those from icecovered antarctic freshwater lakes. Geomicrobiol. J. 4: 269-283

Simmons, G. M., Jr, Love, F. G. (1987). Water quality of newly discovered groundwater discharge into a deep coral reef habitat. In. Cooper, R. A., Shepard, A. N. (eds.) Science applications of current diving technology on the U.S. continental shelf. NOAA Symposium Series for Undersea Research 2(2): 155-163. NOAA Undersea Research Program, Rockville, MD

Simmons, G. M., Jr, Neal, J., Simmons, N., Lacy, D., Chadduck, R., Elliott, K. (1987). Nitrogen fixation potential in a deep coral reef habitat and its importance to submarine groundwater discharge. Virginia Water Resources Forum, April 6-7 Virginia Water Resources Research Center, Blacksburg, VA (Abstr.)

Simmons, G. M., Jr, Netherton, J. (1987). Groundwater discharge in a deep coral reef habitat - evidence for a new biogeochemical cycle? In: Mitchell, C. T (ed.) Proc. Amer Assoc. Underwater Sci., 947 Newhall St., Costa Mesa, CA 92627. p. 1-12

Simmons, G. M., Jr, Reay, W., Smedley, S., Williams, M. (1990). Assessing submarine groundwater discharge in relation to land use. In: Mihursky, J. A., Chaney, A. (eds.)

This manuscript was submitted to the editor
New perspectives in the Chesapeake system. Proceedings of the Chesapeake Bay Research Conference, Dec. 4-9, 1990, Baltimore, MD. CRC Publ. 137. Chesapeake Research Consortium, Solomons, MD, p. 635-644

Simms, M. (1984). Dolomitization by groundwater-flow systems in carbonate platforms. Trans. Gulf Coast Ass. Geol. Soc. 34: 411-420

Skinner, R., Jaap, W. (1986). Trace metals and pesticides in sediments and organisms in John Pennekamp Coral Reef State Park and Key Largo National Marine Sanctuary. Final Rpt. to the Fla. Dept. of Natural Resources, St. Petersburg, FL

Welch, P. S. (1948). Limnological methods. McGraw-Hill, Inc., New York

Wharton, R. A., Jr, Simmons, G. M., Jr, McKay, C. P. (1989). Perennially ice-covered Lake Hoare, Antarctica: physical environment, biology and sedimentation. Hydrobiol. 172: $305-320$

Zeitschel, B. (1979). Sediment-water interaction in nutrient dynamics. In: Tenore, K. R., Coull, B. C. (eds.) Marine benthic dynamics. Univ. of South Carolina Press, Columbia, p. 195-218

Zimmermann, C. F., Montgomery, J. R., Carlson, P. R. (1985). Variability of dissolved reactive phosphate flux rates in nearshore estuarine sediments: effects of groundwater flow. Estuaries 8:228-236

Manuscript first received: September 20, 1990 Revised version accepted: April 24, 1992 